\title{
Linguistic Analysis of the Two Speech Functions in President Donald Trump's Inaugural Speech
}

\author{
Vicky Tchaparian \\ Lebanese University
}

\begin{abstract}
The purpose of this study is the linguistic interpretation of President Donald Trump's inaugural speech during the ceremony held in Washington D. C. on January 21, 2017. The two functions of speech which will be analyzed here are the grammatical and textual functions. The findings reveal two main themes: one is the criticism of the economic situation of America during the last years and the other is a promise and a vow for a change towards a better future where the economy will flourish and there will be prosperity. The study shows the president's determination to make America strong again, safe again, and prosperous again.
\end{abstract}

Key words: Donald Trump, America, rebuilding, power, challenges, grammatical analysis, textual analysis.

\section{Introduction}

The inauguration of the President of the United States is a ceremony which marks the commencement of a new four-year term of the President of the United States. The mentioned ceremony takes place for each new presidential term, even if the president is going to continue in office for a second term.

During his inaugural speech the $45^{\text {th }}$ US President Donald Trump appeared in a special ceremony accompanied by the First Lady Melania Trump, who "brought back memories of Jacqueline Kennedy in an elegant Ralph Lauren powder blue suit" (Donald Trump's First Speech as President 2017). During his 16-minute speech Trump addressed the American people promising them to put America First. He said that the ceremony had a special meaning, 
because it was not a transfer of power from one party or administration to another but a ceremony that belongs to the American people themselves. The speech consists of more than 1450 words which realize grammatical and textual functions. Below is an analysis which will focus on both of the mentioned functions.

\section{Grammatical Function: Modals and Pronouns}

\section{Modality Analysis}

The modal verb will is used mostly while talking about the future, it is the most frequent choice used to make requests, promises, etc. (Thornburg 2004: 30-1,192-3). Must expresses necessity and is usually equivalent to am/is/are obliged. In the second person, it is used chiefly to express a command, or an insistent request or counsel. Considering the above definitions, it can be stated that the usage of the auxiliaries will and must are well justified in the President's speech.

The table below shows the frequency and politeness degree of the auxiliaries will and must in President Trump's speech.

\begin{tabular}{|l|l|l|l|}
\hline Modals & Low politeness & Medium politeness & High politeness \\
\hline Positive modals & - & $30($ will $)$ & $2($ must $)$ \\
\hline Negative modals & - & $3($ will not $)$ & - \\
\hline
\end{tabular}

According to the above table, the auxiliary will is the most excessively used modal. This shows that the president focuses on future plans and is requesting American people to join his efforts for a better future for the country.

\section{Pronoun Analysis:}

The personal pronoun is a grammatical form, a subcategory of the pronoun class, which itself represents a subcategory of noun. Personal pronouns function as the heads of pronoun phrases or noun phrases. They are words that take the place of common and proper nouns. (Huddleston 1984). Detecting the 
number of occurrences of personal pronouns in President Trump's inaugural speech we have drawn the following table:

\begin{tabular}{|l|l|l|}
\hline \multicolumn{2}{|l|}{ Personal pronouns } & $\begin{array}{l}\text { Number of usages in } \\
\text { President Trump's speech }\end{array}$ \\
\hline First person & $I($ me $)$ & 3 \\
\hline & We (us) & 35 \\
\hline Second person & You (your) & 4 \\
\hline Third person & He (him) & - \\
\hline & She (her) & - \\
\hline & It (it) & 9 \\
\hline & They (them) & 2 \\
\hline
\end{tabular}

The above table shows that the President has used the personal pronouns $I$ and me only 3 times, while he has used we and us 35 times. This shows that the President's speech focuses on American people (including himself) rather than only on himself. By this, he aims to share everything with American people. He believes in the power of unity and togetherness. Thus, his effort to make America great again depends more on the President in company with the American people.

As for possessive pronouns, they are pronouns that express possession or some other relationship to another word or phrase and can perform five functions in clauses: subject, subject complement, direct object, indirect object, and prepositional complement. Moreover, the possessive pronoun is a subcategory of pronoun class which in its turn is a subcategory of the noun. Possessive pronouns function as the heads of pronoun phrases or noun phrases (Laurel \& Brinton 2010). Below is a table that shows the number of occurrences of the possessive pronouns in President Trump's inaugural speech. 


\begin{tabular}{|l|l|}
\hline Possessive pronouns: & Number of usages in the president's speech \\
\hline My (mine) & 1 \\
\hline Our (ours) & 38 \\
\hline Your (yours) & 11 \\
\hline His (his) & - \\
\hline Her (hers) & - \\
\hline Its (its) & 9 \\
\hline Their (theirs) & 6 \\
\hline
\end{tabular}

The above table shows that the President has used the possessive pronoun my only once, while using your/yours 11 times and our/ours 38 times. This shows that the President uses the possessive pronouns your/yours and our/ours to reveal that he depends on American people in his effort of unity and making "America great again."

\section{Textual Analysis}

According to M. A. K. Halliday "Language makes links between itself and the situation; and discourse becomes possible because the speaker or writer can produce a text and the listener or reader can recognize one" (Halliday 1979:334). On the other hand, according to Hu Zhuanglin, because language serves a generalized ideational function, we are able to use it for all the specific purposes and types of contexts which involve the communication of experience. Because language serves a generalized interpersonal function, we are able to use it for the specific forms of personal expression and social interaction. A prerequisite to its effective operation under both these headings is what we have referred to as the textual function. When language becomes a text, it is related to itself and to its contexts of use. Without the textual component of meaning, we should be unable to make any use of language at all (Zhuanglin 1988).

Donald Trump's inaugural speech is the President's first experience with the American people to give them a public speech; Mr. Trump wants to impress and 
convince the Americans that he and his team will effectively serve America in the best way possible. He says that he is ready to serve America and the Americans "with every breath" of his body.

The President's inaugural speech is a good example to show that language makes links between itself and the situation to produce a text and the listener or reader can recognize one (Halliday 1979:334), and that language serves a generalized ideational function (Zhuanglin 1988). We have divided the text of the speech into seventeen different parts to clarify its different ideational functions. Below are the parts;

1. Salutation;

2. Togetherness (The president and the people will build America together);

3. Gratitude (to President Obama and his wife for being magnificent);

4. Power transfer (The transfer of power from Washington to the people, not to him as a president);

5. Criticism (There is a decline in economy because those who reaped the fruits of American economy had not been the American people themselves);

6. Promise (Promise for a change for the better. Serving the citizens through schools and education, jobs and cash, safety from crimes, gangs and drugs);

7. Oath (Oath to top the pain of the American people from the terrorists);

8. Oath (Oath for better industry and military);

9. Oath (Oath for a different future, new vision - America First);

10. Americanization (America will benefit the Americans);

11. Fight (Fight for the construction and rebuilding);

12. Civilization (The Civilized world against Islamic terrorism);

13. Unity (Power is in the unity);

14. Timeliness (Time for action not talk, time to take challenges, time for prosperity);

15. Togetherness (With all the differences, Americans unite under the same flag);

16. Promise (Vow to protect the citizens);

17. Strength (Together stronger). 
The text of the President's speech which reveals conversational features is highly persuasive since the President is the one who is leading the talk, who chooses/changes the topics, and comments on what he says. He is the dominant participant who initiates the conversation, sets the agenda, and controls the topics. Mr. Trump is able to convince his submissive participants who are following the set agenda of his speech. He is able to let them believe in him since he reveals the truth about the economic situation being bad. There has been terror and drugs, yet the President says we - he and his fellow citizens together will make America great again.

\section{Conclusion}

Donald Trump entered the 2016 presidential race as a Republican defeating sixteen opponents and announcing his campaign slogan, Make America Great Again. On June 16, 2015, Mr. Trump first announced his candidacy for President of the United States at Trump Tower in Manhattan. His speech included domestic issues such as illegal immigration, offshoring of American jobs, the US national debt, and Islamic terrorism. All these had remained large priorities during his campaign and have all been included in his inaugural speech and vow to work together with the American people for a better America. However, according to Schäffner (1996:203) "politicians do not deliver speeches as individuals, but rather as representatives of political parties, governments, or nations." Thus, Mr. Trump's speech shows not only his own views and promises, but also those of the political party he represents.

The grammatical and textual analyses show that the President's speech consists of different points where he thanks, blames, and promises the citizens. However, what is obvious is that the president wants to look forward to a better future for the American people. A future that is prosperous and safe. He uses short sentences and simple words. First he thanks the previous powers that controlled the country, but he later blames them because they contribute to making other countries prosper economically but have a deficient inside the US (by making the factories and companies close). 
However, with all the negativity that is dominant in the country, the President promises a better future for the Americans where they all work together, since there is power in unity. He believes that all the country from Detroit to Nabraska live under the same American flag, and thus they have all to work together for a better future for America and the Americans.

\section{References:}

1. Brinton, L.J. \& Donna M. Brinton (2010) The Linguistic Structure of Modern English. Amsterdam: John Benjamins.

2. Donald Trump's First Speech as President. Available at: <www.ndtv.com> JSTOR database [Accessed November 2017].

3. Hopper, P.J. (1999) A Short Course in Grammar. New York: W.W. Norton \& Company.

4. Halliday, M.A.K. (1979) Linguistic Function and Literary Style: An Inquiry into the Language of William Golding's "The Inheritors." // Linguistic Studies of Text and Discourse. Peking: Peking University Press, pp. 88-125.

5. Huddleston, R. (1984) Introduction to the Grammar of English. Cambridge: CUP.

6. Schäffner, C. (1996) Editorial: Political Speeches and Discourse Analysis. // Current Issues in Language and Society, 3 (3), pp. 201-204.

7. The Auxiliary Verbs "Must," "Need," and "Dare." Available at: <www.btb.termiumplus.gc.ca/tpv2guides/index-fra.html> JSTOR database [Accessed November 2017].

8. Thornbury, S. (2004) Natural Grammar. Oxford: OUP.

9. United_States_presidential. // Wikipedia. The New Encyclopedia. Available at: <wikipedia.org/wiki/United_States_presidential> JSTOR database [Accessed November 2017].

10.Zhuanglin, H. (1988) A Course of Linguistics. Peking: Peking University Press. 


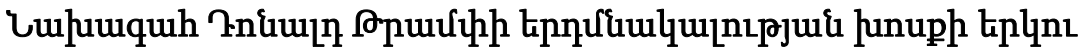

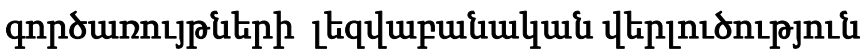

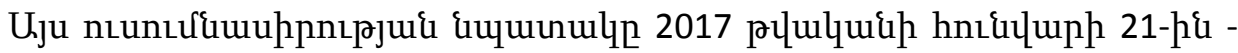

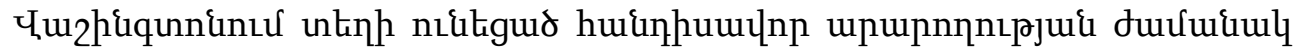

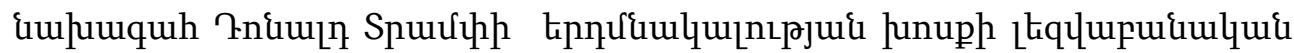

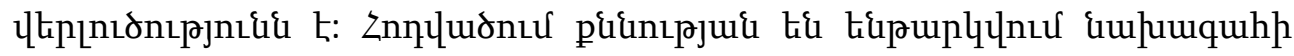

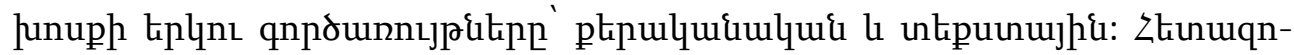

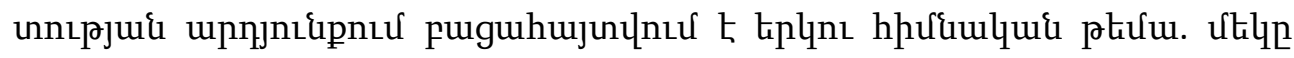

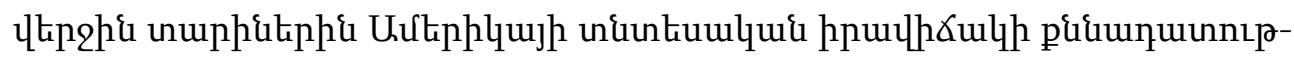

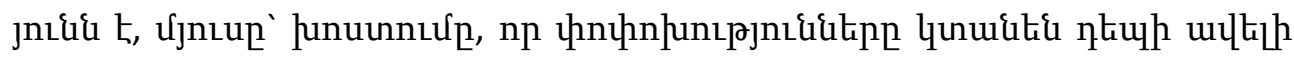

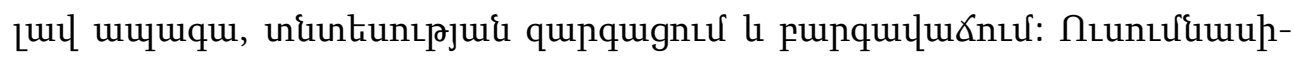

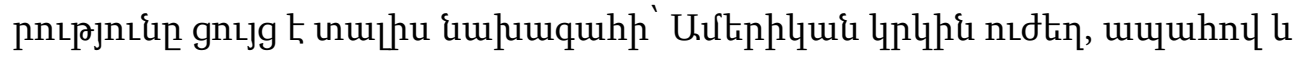

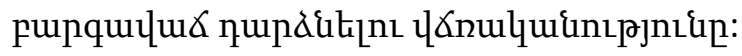

